\title{
The Educational Institution Teachers and Professional Community Representatives' Readiness Formation for the Joint Pupils' Career Guidance Implementation
}

\author{
Kadriya I. Sibgatova ${ }^{1}$, Zulfiya N. Mirzagalyamova ${ }^{1}$, Evgeniya L. Pupysheva ${ }^{2}$, Fairuza I. Mirzanagimova ${ }^{2}$, Inna \\ N. Shkinderova ${ }^{3}$, Elvira N. Nuriyeva ${ }^{4}$, Alfiya R. Masalimova ${ }^{5} \&$ Neile K. Schepkina ${ }^{6}$ \\ ${ }^{1}$ Kazan National Research Technical University named after A.N. Tupolev, Kazan, Russia \\ ${ }^{2}$ Yelabuga Institute of Kazan Federal University, Yelabuga, Russia \\ ${ }^{3}$ Nizhnekamsk Petrochemical College, Nizhnekamsk, Russia \\ ${ }^{4}$ Nizhnekamsk Institute of Chemical Engineering, The branch of Kazan National Research Technological \\ University, Nizhnekamsk, Russia \\ ${ }^{5}$ Kazan Federal University, Kazan, Russia \\ ${ }^{6}$ Amur State University, Blagoveschensk, Russia \\ Correspondence: Kadriya I. Sibgatova, Technical College at Kazan National Research Technical University \\ named after A. N. Tupolev, Kazan, 420111, Russia. E-mail: baina@techcol.kstu-kai.ru
}

Received: October 24, 2014 Accepted: December 3, 2014 Online Published: December 18, 2014

doi:10.5539/res.v7n1p74 URL: http://dx.doi.org/10.5539/res.v7n1p74

\begin{abstract}
The aim of this article is to develop and implement scientific and methodological retraining and professional development of school teachers, teachers of vocational colleges and representatives of the production to the joint implementation of pupils' career guidance. The integrative approach is the basic approach of this problem studying. It involves the integration of education and production joint actions in optimizing pupils' career guidance which can help them to choose their future profession consciously. The paper presents the components, criteria, indicators and levels of subjects' integrated system of "education-production" readiness for the joint implementation of pupils' career guidance. The dynamics as a result of scientific and methodological support is shown here as well. This paper presents a practical value for educational institutions to plan and organize career guidance.
\end{abstract}

Keywords: career guidance work, pupils, school teachers, applicants, representatives of production, enterprise

\section{Introduction}

There is an urgent necessity to bring together educational institutions and industrial structures to organize the process of pupils' personal values and their professional interests' formation in choosing a career in modern conditions of Russian society. Actuality of the education and production integration is caused by the fact that the public life had been radically changed over the past decade. These changes have influenced the formation of the above-mentioned values and interests of pupils greatly and they have broken the usual sequence of events. So the necessity of consolidating the efforts of educational institutions and production structures is the only true way to solve the problems in the actual introduction of career guidance in an integrated system "school—vocational college - enterprise".

However, there are no departments with activity directed towards the organization of career guidance work in collaboration with industry in educational institutions. Lack of funding policies of the activity affects the current labor market negatively because there are not enough mid-level professionals nowadays.

Vocational colleges have the intellectual resources to generate skills that contribute to the choice of the type of training, but do not use them actively in career-oriented work with pupils (Sibgatova, 2010). They contribute to conscious creating of a career path, but there is a lack of integration with enterprises taking into consideration the requirements of modern labor market (Lerner, 2009).

Consequently, there is a necessity for closer links between schools, colleges and enterprises for joint coping with 
common problems. They can be solved if there is a common aim and functional compatibility of main directions of their activity and optimal use of available resources.

\section{Materials and Methods}

The analysis of the current state of career guidance in an integrated system "school—vocational college - enterprise" led to the conclusion that the readiness for pupils' career guidance is an important thing in the structure of professional pedagogical activity. We highlighted a number of components based on the structure of the school and college teachers and representatives of the professional community readiness for the career guidance of entrants. They are: motivational, cognitive, active, emotional and determent, reflex (Zholovan, 2009; Parnov, 2010; Sibgatova, 2011).

\subsection{Motivational Component}

Qualitative characteristic of subjects' integrated system "school—vocational college—enterprise" readiness for the students' and pupils' career guidance according to this component has allowed us to define the following levels.

Low level motivational component is characterized by the lack of awareness as a personal and professional role and significance in helping pupils to choose future professional activity, weak motivation in career guidance organizing, as well as the reluctance of subjects of integrated system "school—vocational college-enterprise" to be engaged in permanent self-education for implementation effective pupils' career guidance.

Intermediate motivational component is characterized by awareness of their role in helping pupils to define their profession. However, we can see here the lack of sufficient positive motive for the implementation and the lack of cognitive interest of the subjects of an integrated system in solving career guidance problems in the fragmented type of their own self-education in the field of pupils' career guidance.

High level of awareness of the motivational component is characterized by the personal role, professional and responsible attitude in organizing of pupils' career guidance, a steady positive motivation in solving problems related to professional pupils' self-determination and high demands to their own self-education in the successful career guidance introduction.

\subsection{Cognitive Component}

The qualitative characteristic of subjects' integrated system "school—vocational college—enterprise" readiness for the pupils" career guidance according to cognitive component is characterized by the following levels

Low level of cognitive component is characterized by insufficient technical knowledge of the implementation of quality career guidance and subsequent weak awareness of professional interests and abilities of the pupils according to the modern requirements of the acquired profession.

Intermediate cognitive component is characterized by sufficient technical knowledge of the proper introduction of pupils' career guidance, but they are accompanied by insufficient awareness of the professional interests of the pupils themselves to familiarize them with the prospects of further professional career.

High level of cognitive component is characterized by a wide range of professional knowledge sufficient to reveal professional interests and abilities of pupils. They correspond not only to the modern requirements of the acquired profession, but also encourage them to strive for career promotion in their future professional activity.

\subsection{Active Component}

Qualitative characteristic of the active component of the subjects' integrated system "school—vocational college - enterprise" readiness for the pupils' career guidance has the following levels.

Low level of the active component is characterized by a deficiency of professional skills and, consequently, by low level of creativity for the organization of career guidance, unable to generate the necessary creativity of pupils to choose their future profession.

Intermediate level is characterized by the professional skills for cognitive activity formation to choose pupils' future profession, however, the lack of creativity of the subjects themselves integrated system "school-vocational college-enterprise" does not allow them to adopt new technologies and ways of organizing career guidance because of insufficient knowledge of the methods of organization.

High level of the activity component is characterized by highly professional skills, by creativity in developing new technologies and methods of career guidance, contributing to cognitive interests that encourage pupils to choose their future profession creatively. 


\subsection{Emotional and Determent Component}

Qualitative characteristic of emotional and determent component subjects' integrated system "school—vocational college - enterprise" readiness for the pupils' career guidance has the following levels.

Low level of this component is characterized by the irresponsibility for the consequences of their actions, indifference to the successful introduction of career guidance, passive attitude to the organization and unwillingness to develop new directions.

Average level of this component is characterized by understanding the role of responsible attitude to pupils' career guidance, but fragmented to achieve its aims because of the subject integrated system "school—vocational college - enterprise" being unready for developing new directions in its organization.

High level is characterized by responsible attitude to direct and hidden consequences of their actions, by confidence in the success of achieving the career guidance work, owing to the high activity of subjects in the organization of career guidance system, willingness to do the work from scratch and having irregular working hours.

\subsection{Reflex Component}

Qualitative characteristic of the reflex component subjects integrated system "school—vocational college - enterprise" readiness for the pupils' career guidance allowed us to determine the following levels.

Low level of reflex component is characterized by insufficient capacity of subjects integrated system "school-vocational college-enterprise" for introspection and therefore an inability to self-criticism and objective self-esteem. Also this level shows that the whole system is not ready to identify and eliminate the causes of problems appeared in pupils' career guidance, because of the weak occupational mobility and ability to overcome the difficulties in this work.

Average level of this component is characterized by self-organization but insufficient efficiency in career guidance introduction, ability for occupational mobility and willingness to change work. But usual stereotypes of working with pupils are used in this case.

High level of this component is characterized by the ability for critical introspection, responsibility to overcome the problems due to the high self-organization, the ability to change usual stereotypes to identify and eliminate the causes of difficulties in pupils' career guidance.

\section{Results}

The experimental work aims were the following:

- to organize retraining for school teachers, college teachers and enterprise representatives-future employers to introduce the course "Theory and practice of career guidance";

- to do the diagnostics of the levels development and teachers' readiness for career guidance introduction before and after the course.

Experimental base: "Technical College" at Kazan State Technical University named after Tupolev; Schools № 1, 14, 42, 43, 51, 81, 84, 85, 96.110, 111, 144, 155, 165 Kazan, gymnasium № 6,102,122 Kazan.

We tested school teachers, vocational colleges and representatives of basic enterprises for being ready to organize career guidance at the early stages of stating experiment. So a questionnaire was designed in such way that allowed to reveal readiness components outlined above (motivation, active, cognitive, emotional and determent and reflex).

84 teachers from schools and 21 teachers from the Technical College, 19 representatives of the professional community took part in the polling. The results of the survey are presented in Table 1. 
Table 1. Diagnostic levels results of school teachers, vocational college teachers and enterprises representatives' readiness formation for the implementation of pupils' career guidance (\%)

\begin{tabular}{llll}
\hline Levels & $\begin{array}{l}\text { Sespondents } \\
\text { teachers }\end{array}$ & $\begin{array}{l}\text { Vocational } \\
\text { teachers }\end{array}$ & college \\
\hline High & 17 & 35 & $\begin{array}{l}\text { Representatives of professional } \\
\text { community }\end{array}$ \\
Average & 16 & 32 & 27 \\
Low & 67 & 33 & 25 \\
\hline
\end{tabular}

Vocational college teachers and enterprise representatives showed the greatest interest and willingness to pupils' career guidance, there were few enthusiasts among teachers but the majority of respondents showed a low level of readiness. Vocational college teachers and school teachers had the most formed active-component because they have to participate in career guidance activities every year. The motivational and cognitive components were the least formed ones among teachers; representatives of the professional community had the least formed cognitive and reflex components. The results of components levels distribution are shown in table 2 .

Table 2. The level of distribution readiness for career guidance according to each component

\begin{tabular}{lllll}
\hline Components & Levels & $\begin{array}{l}\text { School } \\
\text { teachers }\end{array}$ & $\begin{array}{l}\text { Vocational } \\
\text { college teachers }\end{array}$ & $\begin{array}{l}\text { Enterprises } \\
\text { representatives }\end{array}$ \\
\hline motivational & high & 12 & 22 & 26 \\
& average & 27 & 24 & 36 \\
cognitive & low & 61 & 54 & 38 \\
& high & 21 & 27 & 18 \\
& average & 10 & 30 & 20 \\
active & low & 69 & 43 & 62 \\
& high & 37 & 32 & 24 \\
emotional and & average & 26 & 20 & 26 \\
determent & low & 37 & 48 & 50 \\
reflex & high & 30 & 8 & 45 \\
& average & 24 & 24 & 34 \\
& low & 46 & 68 & 21 \\
& high & 35 & 24 & 19 \\
& average & 34 & 22 & 21 \\
& low & 31 & 54 & 60 \\
\hline
\end{tabular}

Besides, the analysis of the questionnaires showed that school teachers and vocational college teachers and basic enterprise representatives almost have no idea how to introduce and organize joint career guidance work. Only $24 \%, 19 \%$ and $30 \%$ of respondents said that they see the necessity of including all the system subjects in career guidance work. Professional community, unlike school teachers were more interested in a joint career guidance work and even suggested the ways of improving communication between educational institutions and industrial complexes in order to work together on the pupils' career guidance. Later some of them have passed retraining course according to our program.

We have considered these and other identified problems in the developed course program "The theory and practice of career guidance" aimed at the formation of an integrated system of the subjects" "school—vocational college - enterprise" readiness for the career guidance introduction.

The purpose of this course was to form the significant personal role of pupils promoting to choose their future profession, positive motive and persistent cognitive interest to career guidance introduction, knowledge. It is 
necessary for the introduction of pupils' career guidance to develop professional skills and competencies to solve career guidance problems, ability to plan and introduce pupils and students' career guidance, and development of an objective assessment and self-assessment of readiness for overcoming difficulties identifying and eliminating their causes in the pupils' career guidance.

The program content allowed revealing of the essence and prospects of school, college and enterprise integration; to show the direction of integration processes in the career guidance activities. This allowed teachers to avoid erroneous opinions about excessive complexity of the process and to see the benefits of the integrated system in the career guidance introduction.

We have covered the maximum number of school and vocational college teachers and representatives of the professional community at the stating stage during questioning in order to be able to compare before and after opinion of those who will take a refresher course. 32 of 84 interrogated school teachers attended the training course. Respectively, 18 of 21 college teachers attended the course. We have identified their first questionnaire after having finished the course and asked to re-answer the questionnaire (the interval was 7 months) (Table 3).

Table 3. The results of diagnostic level of school and vocational college teachers' readiness formation for career guidance work (\%)

\begin{tabular}{lllllll}
\hline Levels & Respondents & \multicolumn{2}{l}{$\begin{array}{l}\text { vocational college } \\
\text { teachers, \% }\end{array}$} & \multicolumn{2}{c}{ school teachers'\% } & \multicolumn{2}{l}{$\begin{array}{l}\text { enterprises } \\
\text { representatives, \% }\end{array}$} \\
\hline \multirow{3}{*}{ High } & Before & After & Before & After & Before & After \\
Average & 25 & 65 & 12 & 41 & 27 & 62 \\
Low & 27 & 32 & 14 & 38 & 25 & 30 \\
\hline
\end{tabular}

Thus, the analysis of the results shows that the trainees' readiness formation for the career guidance activities has been significantly changed.

We held a joint meeting at the enterprises with representatives of the professional community, where the main directions of career guidance in an integrated system "school - vocational college — enterprise" were presented and discussed. The further career guidance work, based on the discussion, was corrected.

\section{Discussions}

The required knowledge that was the prerequisite for the resolution of problems of the study was accumulated in the modern scientific and educational literature: the problem of pupils' career guidance is revealed by Grinshpun, 2004; Zakharov, 1988; Klimov, 2007; Pryazhnikov, 2008; Prutchenkov, 2001, etc.; the motives and factors of pupils' professional self-determination are investigated by Maslow, 1999; Chistyakova, 1993, etc.; the problems of professionally-oriented labor in the system of uninterrupted education are identified by Aitov, 2009; Batyshev, 1999, etc.; the foreign adaptive educational potential organization of pupils' career guidance is revealed by Grinshpun, 2005; Osbaldeston \& Barham, 1999; Shchekin, 2003; Ukke, 1990, etc. The various problems of pupils' career guidance work are discussed in the thesis. In particular: the peculiarities of the organization of career guidance in uninterrupted education are discussed by (Khmeleva, 2002); theoretical and methodological basis for the Pedagogical institutes students' readiness formation for pupils' career guidance work are developed by (Pshenichnov, 2009); organizational and pedagogical conditions of effective professional self-determination of high school pupils are established and developed by (Andreeva, 2010; Shcherbakov, 2006) However, analysis of the scientific and educational literature on research topic and practical activity experience suggest that scientific and methodological subjects' of educational institutions and professional community training in the introduction of joint pupils' career guidance is not enough developed.

\section{Conclusion}

The scientific and methodological support retraining and professional subjects integrated system "school-vocational college - enterprise" on a joint career guidance represented in the study, includes the syllabus, teaching manual "Theory and practice of career guidance," written to improve pupils and students' career guidance work. It allows predicting of schools, colleges and enterprises perspective integration directions. It helps to avoid erroneous opinions about the excessive complexity of the process as well and to realize the 
importance and advantages of joint career guidance.

\section{References}

Aitov, N. A. (1999). About subjectivity and subjectivity. Case Studies, 9, 110-113.

Andreeva, L. I. (2010). Professional self schoolchildren in the innovation activities of educational institution (p. 178) (Thesis PhD, Togliatti).

Batyshev, S. Y. (2009). Professional Pedagogy. Moscow: Association "Vocational Education".

Chistyakova, S. N. (1993). Professional self-determination and career development of young people. Moscow.

Grinshpun, S. S. (2004). Experience creating a civil service career counseling in France. Pedagogy, 7, 85-91.

Grinshpun, S. S. (2005). Professional orientation of students in the United States. Pedagogy, 9, 65-72.

Khmeleva, E. V. (2002). Vocational guidance work with students in continuing education (p. 162) (Thesis PhD, Stavropol).

Klimov, E. A. (2007). Psychology professional self: A textbook for high schools (p. 304). Moscow: Academy.

Lerner, P. S. (2009). As a factor in career counseling students training for prospective Russian economy. The world of education -Education in the world, 3, 3-13.

Maslow, A. (1999). Motivation and Personality (p. 322). St. Petersburg: Eurasia.

Osbaldeston, M., \& Barham, K. (1999). Developing managers for the future: Current provision and future needs. J. Eur. Ind. Training, 4, 5-10.

Parnov, D. A. (2010). Training in school—Effective career guidance. Vocational education. Capital, 5, 19-20.

Prutchenkov, A. S. (2001). Socio-psychological training in school (p. 640). Moscow: Eksmo-Press.

Pryazhnikov, N. S. (2008). Vocational guidance in the school and college: Games, exercises, questionnaires. In 8-11 classes Vocational College: Teaching material (p. 288). Moscow: WACO.

Pshenichnov, A. N. (2009). Formation of readiness for career-oriented work with students of pedagogical high school students (p. 124). Thesis $\mathrm{PhD}$, Shuya.

Shchekin, G. V. (2003). Theory and practice of human resource management (p. 87). AIDP.

Shcherbakova, T. V. (2006). Support of professional self-pupils of the city as the organizational and pedagogical problem (p. 190) (Thesis PhD, Novgorod).

Sibgatova, K. I. (2010). Professional adaptation of future technical specialists in the integration of educational institutions and enterprises customers frames. Kazan Pedagogical Journal, 3, 99-105.

Sibgatova, K. I. (2011). Model of career guidance in an integrated system "school-college-enterprise". Kazan Pedagogical Journal, 1, 83-90.

Ukke, Y. (1990). Diagnosis conscious choice of profession among Japanese schoolchildren. Questions of Psychology, 5, 150-151.

Zakharov, N. N. (1988). Professional orientation of students (p. 134). Moscow: Education.

Zholovan, S. V. (2009). Personnel policies and guidance workforce in St. Petersburg. Vocational education, Capital, 3, 18-19.

\section{Copyrights}

Copyright for this article is retained by the author(s), with first publication rights granted to the journal. This is an open-access article distributed under the terms and conditions of the Creative Commons Attribution license (http://creativecommons.org/licenses/by/3.0/). 